\title{
Cutting Edge Approach on Prodrug: Contrivance for Target Drug Delivery
}

Y M Varsha ${ }^{1 *}$, G Ram Mohan Rao² and V Venkateswara Rao'

${ }^{1 *}$ School of Chemical and Biotechnology, SASTRA University, Tamil Nadu, India

${ }^{2}$ School of Bio-Engineering, SRM University, Tamil Nadu, India

\begin{abstract}
Drug administration procedures are very much vital and are considered to be the prime-most criteria during the drug design and its appliance. Scrutinizing this, drugs are designed in such a way, bringing some change in their persona like bioavailability and bioequivalence. One such approach called prodrug, first started in 1950's is still a fertile area of research because of it's insist persona. Prodrugs are the shrouded drugs which are one or two chemical or enzymatic steps away from the active parent drug. Present review delineates about the prodrug action, types of prodrugs, new prodrug therapies, nanotech allied prodrugs.
\end{abstract}

Keywords: Prodrug; Bioequivalence; Pro-prodrug; Mutual prodrug; Nanoparticles

Abbreviations: 5-ASA: 5-Amino Salicylic Acid; AZT: Azidothymidine; ADC: Antibody-directed catalysis; ADEPT: Antibody-directed enzyme prodrug therapy; GDEPT: Gene-directed enzyme prodrug therapy; VDEPT: Virus-directed enzyme prodrug therapy; PDEPT: Polymer-Directed Enzyme Prodrug Therapy; LEAPT: Lectin-directed enzyme-activated prodrug therapy; CDEPT: Clostridial-directed enzyme prodrug therapy; MSN:Mesoporous silica nanoparticles; GNP: gold nanoparticles; SNP: silver nanoparticles; SLM: Solid Lipid Microparticles.

\section{Introduction}

A drug is a small organic molecule introduced in to the body for cure, prevention, treatment or diagnosis of disease or else used to improve mental and physical well-being. This generally binds to the specific site or organ /cell and activates or inhibits the function of the desired biomolecule [1]. When a drug is injected/swallowed/inhaled, they find their way into the bloodstream and are transported to different parts of the body, finally reaching the targeted cell/tissue. Drug may be obliging or damaging, which depends on the kind of drug taken, how much is taken, how often it is used, how quickly it reaches the target, and what other drugs, food, or substances are taken at the same time. Drug administration is associated with certain problems like biodistribution of pharmaceuticals throughout the body, undesirable side-effects due to high drug doses, lack of drug specific affinity toward a pathological site, need of a large total dose of a drug to achieve high local concentration; non-specific toxicity etc. [2,3]. Like such, several challenges are unmet and there is a need of new techniques for drug developments and their application [4].

Pharmacotherapists and other concerned researchers have made their efforts to reduce the frequency of the dosages taken by the patient, drug side effects, and fluctuation in circulating drug levels by introducing targeted drug delivery system [5-8], which have a protected drug interaction with the diseased tissue. Although seemed to be a costlier process, shows a prolonged, localized effect on the specific targeted cell/ tissue [9]. Chemical eradication of undesirable properties of the drug (low oral absorption properties, bad taste, odor etc) is done mainly by designing and developing the drug in the favored approach. Moreover bioequivalence and bioavailability studies are considered as important measures, so that the designed drug can be applied in a right way [1012]. Keeping all these in mind, one such amendment which came in to existence is the Prodrug, defined to be chemically modified inert drug precursor which can be biotransformed in to active parental molecule. Prodrug is considered as an innovative and very interesting strategy bringing adaptation in the drug delivery process by improving the bioavailability of various drugs like Docarpamine, Etilevodopa, Xeloda etc. [13]

\section{Prodrug Notion}

Prodrug or proagent is the masked form of active drug, introduced by Albert and et al. in 1950s, to increase the efficiency of drugs and to decrease its associated toxicity. Though given many names like latentiated drugs (since the concept was discussed in late 1950s), bioreversible derivatives, congeners, prodrugs suits a lot and is commonly accepted term [14]. Appropriate exploit of Prodrugs was only since the late 19th century, which mainly focused to improve undesirable properties of drugs [15]. Prodrugs can be defined as pharmacologically inert chemical derivatives that can be transformed in vivo to the active drug molecules, enzymatically or nonenzymatically, to wield a therapeutic effect $[16,17]$.

As shown in Figure 1, prodrug is considered to be the combination of active drug and side chain/ligand (covalently linked) which helps in targeting the specific cell/tissue. Prodrug is converted to the original drug once it reaches the site of action, followed by rapid abolition of the released derivatizing group without causing side effects.

\section{Persona of an imperative prodrug}

An ideal prodrug should have the following characteristics so as to be released in the pharma market $[18,19]$

- Readily transported to the site of action (active or passive transport across biological barrier)

- Rapid transformation in to active form (Must be selectively

*Corresponding author: Y.M. Varsha, School of Chemical and Biotechnology SASTRA University, India, E-mail: varsha_ym@yahoo.com

Received December 10, 2011; Accepted December 24, 2011; Published December 26, 2011

Citation: Varsha YM, Ram Mohan Rao G, Venkateswara Rao V (2011) Cutting Edge Approach on Prodrug: Contrivance for Target Drug Delivery. J Bioequiv Availab 3: 286-290. doi:10.4172/jbb.1000100

Copyright: (C) 2011 Varsha YM, et al. This is an open-access article distributed under the terms of the Creative Commons Attribution License, which permits unrestricted use, distribution, and reproduction in any medium, provided the original author and source are credited. 
cleaved to the active drug utilizing special enzymatic profile of the site)

- Once the prodrug is selectively generated at the site of action, the tissue must retain the active drug without further degradation

- Release non-toxic metabolic fragments after its transformation with rapid elimination

\section{Prodrug: Categorization}

Figure 2 elucidates about the classification of prodrugs based on cellular site of bioactivation and methods of bioactivation. Bioactivation of drugs may be intracellular or extracellular. Hepatic cells, liver cells etc. relay on metabolic enzymes for Prodrug to be converted to active drug intracellularly. Carbamazepine (anticonvulsant used for treatment of bipolar disorder), Captopril (ACE inhibitors used to treat some types of congestive heart failure), Psilocybin (naturally occurring Prodrug produced by small mushrooms like Psilocybe cubensis, $P$. semilanceata etc). While some antimicrobial and chemotherapy agents like Procytox, Purinethol (immunosuppressive drug), azidothymidine (AZT, a class of antiretroviral drug acting on HIV) intracellularly acts directly on the specific tissue/cell. Extracellular bioactivation may occur in gastrointestinal fluids or in other extracellular fluids. Common

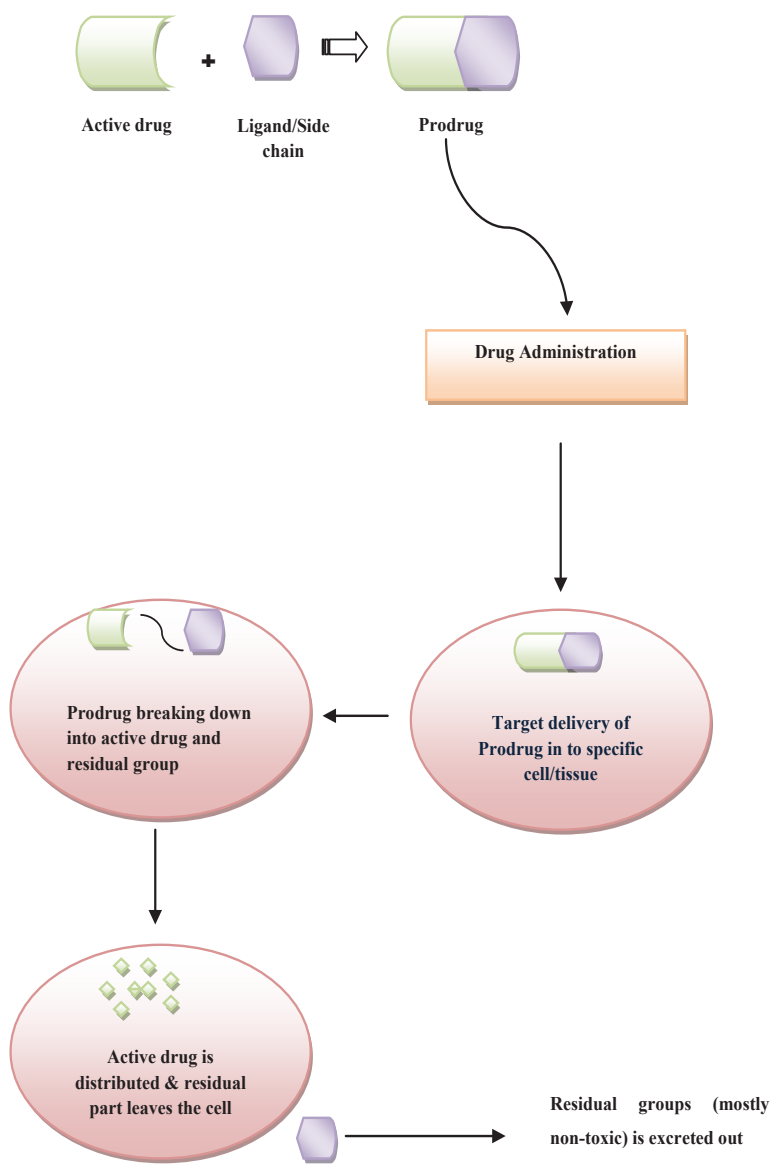

Figure 1: Prodrug action on targeted cells

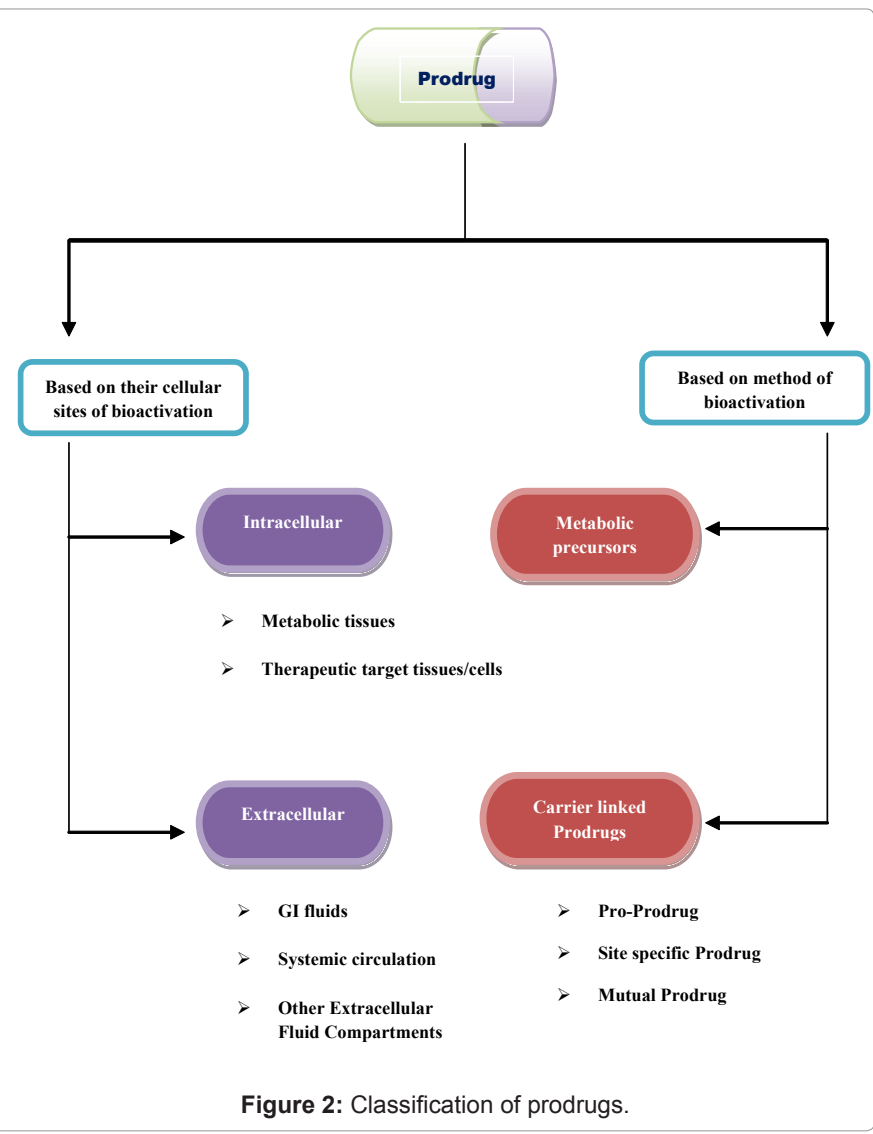

prodrugs which tracks extracellular bioactivation are Chloramphenicol succinate, Bacampicillin (penicillin antibiotic), Dipivefrine (used to treat glaucoma), Azulfidine (used to treat rheumatoid arthritis) etc. [20].

A Prodrug is mainly designed to attain smooth and apposite bioactivation. Based on the method of bioactivation the system or the body needs, prodrugs are equipped with some metabolic precursors or any ligands/carriers. Prodrugs with bioprecursors are due to some simple chemical modifications like redox reactions, while Prodrug carrying a ligand or any inert carrier like ester, amide, phosphate [21] can be alienated in to Pro-prodrug, Site specific Prodrug, Mutual Prodrug.

- Pro-prodrug, also called as double prodrug formed by the technique called cascade latentiation is made of two side chain or ligand derivatives (unstable bonds), mostly ester molecules where the first ester is cleaved enzymatically and the second one under goes non-enzymatic/chemical hydrolysis [22]. Roberta et al reported L-Lysine Pro-Prodrug Containing trans-Ferulic Acid for 5-Amino Salicylic Acid (5-ASA) Colon delivery, to treat Crohn disease [23].

- Site specific Prodrug functions mainly as transporter of the active drug which targets to the desired or specific tissue/cell. Most of the prodrugs are designed to target the specific cell which is contented by this type of Prodrug. Antibody-directed catalysis (ADC) consisting of $\mathrm{F}(\mathrm{ab})$ - $\beta$-lactamase conjugates and a cephalosporin derivative of the oncolytic agent 4-desacetylvinblastine-3-carboxhydrazide are best apposite example for the site specific prodrugs [24]. 
- Mutual Prodrug incorporates two pharmacologically active agents, each acting as promoiety for the other agent. In this the carrier molecule is a drug which helps in overcoming side effects caused by the parent active drug, improving site specificity etc. The best example of mixed drug is Paracodol, a generic pain killer which is thecombination of paracetamol and codeine [25].

\section{Prodrug Therapy}

The prodrug design includes an unfixed position that can be altered to improve in membrane permeability, solubility or absorption, distribution, metabolism, and elimination (ADME) properties. Different Prodrug/ enzyme systems used for cancer therapies and other related therapies includes

- Antibody-directed enzyme prodrug therapy

- Gene-directed enzyme prodrug therapy

- Virus-directed enzyme prodrug therapy

- Polymer-Directed Enzyme Prodrug Therapy

- Lectin-directed enzyme-activated prodrug therapy

- Clostridial-directed enzyme prodrug therapy

\section{Antibody-Directed enzyme prodrug therapy (ADEPT)}

In this targeted therapy, tumor-specific antibody-enzyme conjugate is administered followed by a non-toxic prodrug after a specific time interval [26]. The antibody-enzyme conjugate will help in selective binding of enzyme to the tumor cell and then the prodrug converts in to active drug (toxic) by this targeted enzyme, thus only affecting the tumor and leaving back the normal cells. This idea of using antibodies to carry a specific enzyme to the tumor was explored by Philpott et al. [27]. The first clinical trial of this is done using benzoic acid mustard L-glutamate, which is cleaved by carboxypeptides G2 to give L-glutamic acid and the more toxic nitrogen mustard derivative of benzoic acid [28].

\section{Gene-Directed enzyme prodrug therapy (GDEPT)}

GDEPT, also known as suicide gene therapy is a similar targeted technique where the gene for foreign enzyme is delivered (mostly by Liposomal or polymer mediated gene delivery) [29-35] to the tumor cell which further activates the non toxic prodrug at the site of action [35]. Here the genes are controlled at transcription site by using specific promoter that becomes active in target cells transcribing to mRNA which further translates in to protein. GDEPT genes are isolated from different bacteria, yeast, plants, and viruses. The best studied system which is under the clinical trials is herpes virus thymidine kinase (TK), used with the cold-sore drug ganciclovir (GCV), which is converted to a DNA synthesis inhibitor that is only active in dividing cells [37]. Many genetic modifications and mutations can be done to bring up this technique in effortless way. In certain cases, it is alleged that a single dose of this GDEPT gene will aid in bringing change in the tumor count.

\section{Virus-Directed enzyme prodrug therapy (VDEPT)}

In this pharmacologically oriented gene therapy, viral vector encoding the prodrug-activating enzyme are used followed by efficient treatment with prodrug to attain high levels of activated cytotoxic at the proposed site of action. VDEPT has three possible resource of toxicity: vector, prodrug, and the vector/prodrug combination. It has been reported that, a VDEPT approach using the gene suicide system NTR/ CB1954 (E. coli nitroreductase enzyme/ prodrug CB1954) combination appears promising for the treatment of cancer metastatic to the liver and the peritoneum [38]. Many such different viral, plasmid, retroviral, adenoviral vectors are used nowadays for this target delivery process.

\section{Polymer-Directed enzyme prodrug therapy (PDEPT)}

A novel two step antitumor approach where the polymeric prodrug is administered, first promoting tumor targeting and later activating polymer-enzyme conjugate (PEG-L-asparginase). Here the polymer enzyme conjugates are used as drug carrier or linker, used as anticancer agent [39]. This strategy is presently under phase I/II which includes conjugates like $\mathrm{N}$-(2-hydroxypropyl) methacrylamide (HPMA) copolymer-doxorubicin (PK1, FCE28068), HPMA copolymer-paclitaxel (PNU 166945) etc. [40,41]. A recent technique involving the same technique is polymer-enzyme liposome therapy (PELT) that can cause explosive release of drug from either polymeric prodrugs or liposomes within the tumor interstitium. Another novel technology, microsphere carrier systems made from biodegradable polymers, having bioadhesive property is coming in to picture dealing with the disease Myasthenia Gravis [42].

\section{Lectin-Directed enzyme-Activated prodrug therapy (LEAPT)}

LEAPT is a biparticle drug delivery system that exploits endogenous carbohydrate-to-lectin binding to localize glycosylated enzyme which determines site of drug release and a capped prodrug released by that enzyme [43]. Since this is a new emerging technique, only little information has been shared regarding this and more have to be explored yet.

\section{Clostridial-Directed enzyme prodrug therapy (CDEPT)}

A fact of tumor-targeting properties of nonpathogenic strains of Clostridia and spores which are incapable of germinating in healthy tissue made researchers to bring this novel technique called Clostridial-directed enzyme prodrug therapy [44]. This came in to existence when Minton et al declared that therapeutic proteins delivered using clostridial spores have been prodrug converting enzymes [45]. Specific reports on nitroreductase (NTR) class which converts the 4-nitrogroup of the prodrug CB1954 (5-aziridinyl-2,4-dinitrobenzamide) to toxic 4-hydroxylamine (4HX) derivative (apoptosis-inducing agent) bought evidence to bring up this efficient therapy to treat many cancers [46].

\section{Prodrug as a Part of Nanoworld}

Researchers are now indulged to apply nanotechnology in designing the prodrugs for better delivery of drugs to the targeted site (targeting being an publicized promise of nanotechnology) [47-49], to increase its reactivity, to increase its surface-volume ratio [50,51], to reduce the toxicity (for good safety and biocompatibility) [52] and also to retain their lifespan till it reaches the site of action [53-58].

Mesoporous silica nanoparticles (MSN) [59,60], gold nanoparticles (GNP) [61,62], silver nanoparticles (SNP) [63-65], Solid Lipid Microparticles (SLM) [66,67] etc are used as nanocarriers/polymeric nanoparticles [68,69], nanoshells (concentric particle coated with thin layer of inert coat) [70], which will protect the drug from chemical/ enzymatic degradation and enhance bioavailability [71-73].

Targeted nanozyme delivery technique is considered as boon in treatment of nuero-disorders like Parkinson's disease [74]. In Silico, computer aided designs are carried out prior, before the actual applica- 
Citation: Varsha YM, Ram Mohan Rao G, Venkateswara Rao V (2011) Cutting Edge Approach on Prodrug: Contrivance for Target Drug Delivery. J Bioequiv Availab 3: 286-290. doi:10.4172/jbb.1000100

tion of such prodrugs to optimize the nanoparticle's surface parameters and other related aspects [75]. Recent reports made it clear that, this advancement added a plus point to discover a bolaamphiphilic prodrug, zidovudine-phosphoryl-deoxycholyl didanosine (ZPDD) containing two different drugs (zidovudine and didanosine) in a single molecule and thus simultaneously deliver two types of drugs to targeted tissues proving to be promising nanomedicine [76].

\section{Conclusion}

Prodrug approach is setting a good example for the target drug delivery process which uses simple designing process considering the site of action, targeted cell/tissue, type of administration etc. The strapping prop up for this is the large fraction of newly approved drugs that are prodrugs and similar inclination in the patent literature. Different categories of prodrugs like pro-prodrugs, mutual drugs etc have been discussed each having their own specificities to be used as a patented drug. In the current appraisal, prodrug/enzyme related therapies are conversed giving importance mainly to the targeted drug delivery process considering different carrier molecules like antibody, virus, gene, polymers etc used to direct the drug towards the site of action. Nanocarriers used for progdrug delivery stratagem procured revolution in the present era of drug administration, proving its capability as enhanced nanomedicine.

\section{References}

1. Ravali R, Phaneendra M, Bhanu Jyothi K, Ramya Santhoshi L, Sushma K (2011) Recent Trends in Analytical Techniques for the Development of Pharmaceutical Drugs. J Bioanal Biomed S11.

2. Torchilin VP (2000) Drug Targeting. Eur J Pharm Sci 2: S81-91

3. Griffi ni P, James AD, Roberts AD, Pellegatti M (2010) Metabolites in Safety Testing: Issues and Approaches to the Safety Evaluation of Human Metabolites in a Drug that is Extensively Metabolized. J Drug Metabol Toxicol 1: 102.

4. Arun B (2009) Challenges in Drug discovery: Can We Improve Drug Development. J Bioanal Biomed 1: 50-53.

5. Wee T, Jenssen H (2009) Influenza Drugs - Current Standards and Novel Alternatives. J Antivir Antiretrovir 1: 1-10.

6. Peramo A (2010) Novel Double Lumen Catheter for Drug Delivery at the SkinCatheter Interface. J Tissue Sci Eng 1: 102.

7. Muro S (2011) Efficient and Safe Intra-cellular Transport of Targeted Nanomedicines: are we there Yet? J Nanomedic Biotherapeu Discover 1: 106e.

8. Bareggi Renato NV, Paola N (2010) New Targeted Therapies Against Breast Cancer. J Carcinogene Mutagene 1: 110.

9. de Almeida VR, Brunetto AL, Schwartsmann G, Roesler R, Abujamra AL (2011) De-mystifying the Epigenetic Free for All: Pharmacophore Modeling for Epigenetic Cancer Therapy. Pharm Anal Acta 2: 102e.

10. Najib NM, Salem I, Idkaidek NM (2009) Effect of Replicate Design on Drug Variability and Bioequivalence in Humans. J Bioanal Biomed 1: 14-16.

11. Najib NB, Salem I, Hasan R, Idkaidek NM (2009) Effect of Truncated AUC Method on Drug Bioequivalence in Humans. J Bioequiv Availab 1: 112-114.

12. Nanjwade BK, Derkar GK, Bechra HM, Nanjwade VK, Manvi FV (2011) Design and Characterization of Nanocrystals of Lovastatin for Solubility and Dissolution Enhancement. J Nanomedic Nanotechnol 2: 107.

13. Krishnaiah YSR (2010) Pharmaceutical Technologies for Enhancing Oral Bioavailability of Poorly Soluble Drugs. J Bioequiv Availab 2: 28-36.

14. Harper NJ (1962) Drug Latentiation. Prog Drug Res 4: 221-294.

15. Kristiina MH, Raunio H, Rautio J (2011) Prodrugs-from Serendipity to Rational Design. Pharmacological Reviews 63: 750-771.

16. Sinkula AA, Yalkowsky SH (1975) Rationale for Design of Biologically Reversible Drug Derivatives: Prodrugs. J Pharm Sci 64: 181-210.

17. Stella VJ, Charman WN, Naringrekar VH (1985) Prodrugs. Do they have
Advantages in Clinical Practice? Drugs 29: 455-473.

18. Surya Prakash Rao H (2003) Capping Drugs: Development of Prodrugs. Resonance 19-27.

19. Tegeli VS, Thorat YS, Chougule GK, Shivsharam US, Gajeli GB, et al. (2010) Review on Concepts and Advances in Prodrug Technology. International Journal of Drug Formulation \& Research 1: 32-57.

20. http://en.wikipedia.org/wiki/Prodrug

21. Dang Q, Reddy KR, Kasibthatla SR, Jiang T, Taplin F, et al. (2010) Discovery of Phosphonic Acid-Containing Desaminobenzimidazoles as Fructose 1,6-Bisphosphatase Inhibitors that are Suitable for Oral Delivery via Prodrugs. J Diabetes Metab 1: 105

22. Pandeya SN (1997) An Introduction to Drug Design. (2006 Edition), New Age International (P) Ltd. Publishers, New Delhi, India.

23. Cassano R, Trombino S, Cilea A, Ferrarelli T, Muzzalupo R et al. (2010) L-Lysine Pro-Prodrug Containing trans-Ferulic Acid for 5-Amino Salicylic Acid Colon Delivery: Synthesis, Characterization and in Vitro Antioxidant Activity Evaluation. Chem Pharm Bull 58: 103-105.

24. Meyer DL, Jungheim LN, Law KL, Mikolajczyk SD, Shepherd TA, et al (1993) Site-specific Prodrug Activation by Antibody- $\beta$-Lactamase Conjugates: Regression and Long-Term Growth Inhibition of Human Colon Carcinoma Xenograft Models. Cancer Res 53: 3956-3963.

25. Quintas LEM, Gram KRS, da Silveira GPE, Lopes DVS, Pôças ESC (2011) Pharmacokinetic Modifications and Drug-Drug Interactions in Clinical Monitoring of the Elderly: A Short Review. Pharm Anal Acta 2: 141.

26. Bagshawe KD (2006) Antibody-Directed Enzyme Prodrug Therapy (ADEPT) for Cancer. Expert Rev Anticancer Ther 6: 1421-1431.

27. Bagshawe KD, Sharma SK, Springer CJ, Rogers GT (1994) Antibody Directed Enzyme Prodrug Therapy (ADEPT) A Review of Some Theoretical, Experimental and Clinical Aspects. Annals of Oncology 5: 879-891.

28. Mauger AB, Burke PJ, Somani HH, Friedlos F, Knox RJ (1994) Self-Immolative Prodrugs: Candidates for Antibody-Directed Enzyme Prodrug Therapy in Conjunction with a Nitroreductase Enzyme. J Med Chem 37: 3452-3458.

29. Afergan E, Najajreh Y, Gutman D, Epstein H, Elmalak O, et al. (2010) ${ }^{31}$ P-NMR and Differential Scanning Calorimetry Studies for Determining Vesicle's Drug Physical State and Fraction in Alendronate Liposomes. J Bioanal Biomed 2 125-131.

30. Khan DR (2010) The Use of Nanocarriers for Drug Delivery in Cancer Therapy J Cancer Sci Ther 2: 58-62.

31. Arpke RW, Cheng PW (2011) Characterization of Human Serum AlbuminFacilitated Lipofection Gene Delivery Strategy. J Cell Sci Ther 2: 108.

32. Dibirdik I, Yiv S, Qazi S, Uckun FM (2010) In vivo Anti-Cancer Activity of a Liposomal Nanoparticle Construct of Multifunctional Tyrosine Kinase Inhibitor 4-(4'-Hydroxyphenyl)-Amino-6,7-Dimethoxyquinazoline. J Nanomedic Nanotechnolo 1: 101.

33. Shih MF, Wu CH, Cherng JY (2011) Bioeffects of Transient and LowIntensity Ultrasound on Nanoparticles for a Safe and Efficient DNA Delivery. J Nanomedic Nanotechnol S3: 1.

34. Eshita Y, Higashihara J, Onishi M, Mizuno M, Yoshida J, et al. (2011) Mechanism of the Introduction of Exogenous Genes into Cultured Cells Using DEAE-Dextran-MMA Graft Copolymer as a Non-Viral Gene Carrier. II. Its Thixotropy Property. J Nanomedic Nanotechnol 2: 105.

35. Vaghasia N, Federman N (2011) Liposomes for Targeting Cancer: One Step Closer to the Holy Grail of Cancer Therapeutics? J Nanomedic Biotherapeu Discover 1: $105 \mathrm{e}$.

36. Ram Z, Culver KW, Walbridge S, Blaese RM and Oldfield EH (1993) In Situ Retroviral-Mediated Gene Transfer for the Treatment of Brain Tumours in Rats. Cancer Res 53: 83-88.

37. Both GW (2009) Gene-directed Enzyme Prodrug Therapy for Cancer: A Glimpse into the Future? Discov Med 8: 97-103.

38. Chung-Faye G, Palmer D, Anderson D, Clark J, Downes M, et al. (2001) Virusdirected, Enzyme Prodrug Therapy with Nitroimidazole ReductaseA Phase and Pharmacokinetic Study of its Prodrug. Clin Cancer Res 7: 2662-2668.

39. Plassat V, Renoir JM, Autret G, Marsaud V, Ménager C, et al. (2011) Systemic 
Citation: Varsha YM, Ram Mohan Rao G, Venkateswara Rao V (2011) Cutting Edge Approach on Prodrug: Contrivance for Target Drug Delivery. J Bioequiv Availab 3: 286-290. doi:10.4172/jbb.1000100

Magnetic Targeting of Pure-Antiestrogen-Loaded Superparamagnetic Nanovesicles for Effective Therapy of Hormone-Dependent Breast Cancers. J Bioanal Biomed S2: 1.

40. Duncan R, Gac-Breton S, Keane R, Musila R, Sat YN, et al. (2001) PolymerDrug Conjugates, PDEPT And PELT: Basic Principles for Design and Transfer from the Laboratory to Clinic. J Control Release 6: 135-146.

41. Sun CZ, Lu CT, Zhao YZ, Guo P, Tian JL, et al. (2011) Characterization of the Doxorubicin-Pluronic F68 Conjugate Micelles and Their Effect on Doxorubicin Resistant Human Erythroleukemic Cancer Cells. J Nanomedic Nanotechnol 2: 114

42. Nanjwade BK, Parikh KA, Deshmukh RV, Nanjwade VK, Gaikwad KR, et al. (2011) Development and Evaluation of Intranasal Mucoadhesiv Microspheres of Neostigmine Bromide. Pharm Anal Acta 2: 118.

43. Garnier P, Wang XT, Robinson MA, van Kasteren S, Perkins AC, et al. (2010) Lectin-Directed Enzyme Activated Prodrug Therapy (LEAPT): Synthesis and Evaluation of Rhamnose-Capped Prodrugs. J Drug Target 18: 794-802.

44. Shie-Chau Liu, Ahn G, Mitomu K, Mary JD, Patterson AV, et al. (2008) Optimized Clostridium-Directed Enzyme Prodrug Therapy Improves the Antitumor Activity of the Novel DNA Cross-Linking Agent PR-104. Cancer Res 68: 7995-8003.

45. Minton NP, Mauchline ML, Lemmon MJ, Brehm JK, Fox M, et al. (1995) Chemotherapeutic Tumour Targeting using Clostridial Spores. FEMS Microbiol Rev 17: 357-364

46. Palmer DH, Milner AE, Kerr DJ, Young LS (2003) Mechanism of Cell Death Induced by the Novel Enzyme-Prodrug Combination, Nitroreductase/CB1954 and Identification of Synergism With 5-Fluorouracil. Br J Cancer 89: 944-950.

47. Rosen JE, Yoffe S, Meerasa A, Verma M, Gu FX (2011) Nanotechnology and Diagnostic Imaging: New Advances in Contrast Agent Technology. J Nanomedic Nanotechnol 2: 115.

48. Kanwar JR, Zhou SF, Gurudevan S, Barrow CJ, Kanwar RK (2011) Toll Like Receptors Play a Role in General Immunity, Eye Infection and Inflammation: TIrs for Nanodelivery. J Clin Cell Immunol 2: 114.

49. Yun Y, Conforti L, Muganda P, Sankar J (2011) Nanomedicine-based Synthetic Biology. J Nanomedic Biotherapeu Discover 1: 102e.

50. Abd el-Razek NEE, Shoman SA, Mohamed AF (2011) Nanocapsulated Rift Valley Fever Vaccine Candidates and Relative Immunological and Histopathological Reactivity in Out Bred Swiss Mice. J Vaccines Vaccin 2: 115.

51. Achyuthan K (2011) Whither Commercial Nanobiosensors? J Biosens Bioelectron 2: $102 \mathrm{e}$.

52. De Jong WH, Borm PJA (2008) Drug delivery and nanoparticles: applications and hazards. International journal of nanomedicine 3: 133-49.

53. Vijaya Shanti B, Mrudula T,Naga Deepth CH, Sree VenkateshwarluY (2011) Novel Applications of Nanotechnology in Life Sciences. J Bioanal Biomed S11.

54. Shakeel F, Ramadan W, Shafiq S (2009) Solubility and Dissolution Improvement of Aceclofenac using Different Nanocarriers. J Bioequiv Availab 1: 0 39-043.

55. Caraglia M, Rosa GD, Abbruzzese A, Leonetti C (2011) Nanotechnologies: New Opportunities for Old Drugs. The Case of Aminobisphosphonates. J Nanomedic Biotherapeu Discover 1: 103e.

56. Lukianova-Hleb EY, Oginsky AO, Shenefelt DL, Drezek RA, Hafner JH, et al. (2011) Rainbow Plasmonic Nanobubbles: Synergistic Activation of Gold Nanoparticle Clusters. J Nanomedic Nanotechnol 2: 104

57. Thomas S, Waterman P, Chen S, Marinelli B, Seaman M, et al. (2011) Development of Secreted Protein and Acidic and Rich in Cysteine (SPARC) Targeted Nanoparticles for the Prognostic Molecular Imaging of Metastatic Prostate Cancer. J Nanomedic Nanotechnol 2: 112.

58. Saboktakin MR, Tabatabaie RM, Maharramov A, Ramazanov MA (2011) Synthesis and Characterization of Biodegradable Thiolated Chitosan Nanoparticles as Targeted Drug Delivery System. J Nanomedic Nanotechnol S4: 1.

59. Douroumis D (2011) Mesoporous silica Nanoparticles as Drug Delivery System. J Nanomedic Nanotechnol 2: 102e.

60. Patil A, Chirmade UN, Trivedi V, Lamprou DA, Urquhart A, et al. (2011) Encapsulation of Water Insoluble Drugs in Mesoporous Silica Nanoparticles using Supercritical Carbon Dioxide. J Nanomedic Nanotechnol 2: 111.
61. Rosarin FS, Mirunalini S (2011) Nobel Metallic Nanoparticles with Nove Biomedical Properties. J Bioanal Biomed 3: 85-91.

62. Mustafa T, Watanabe F, Monroe W, Mahmood M, Xu Y, et al. (2011) Impact of Gold Nanoparticle Concentration on their Cellular Uptake by MC3T3-E1 Mouse Osteoblastic Cells as Analyzed by Transmission Electron Microscopy. J Nanomedic Nanotechnol 2: 118.

63. Rosarin FS, Mirunalini S (2011) Nobel Metallic Nanoparticles with Nove Biomedical Properties. J Bioanal Biomed 3: 085-091.

64. An NT, Dong NT, Hanh PTB, Nhi TTY, Vu DA, et al. (2010) SilverNcarboxymethyl Chitosan Nanocomposites: Synthesis and its Antibacterial Activities. J Bioterr Biodef 1: 102

65. Zheng J, Clogston JD, Patri AK, Dobrovolskaia MA, McNeil SE (2011) Sterilization of Silver Nanoparticles Using Standard Gamma Irradiation Procedure Affects Particle Integrity and Biocompatibility. J Nanomedic Nanotechnol S5: 1

66. Nanjwade BK, Patel DJ, Parikh KA, Nanjwade VK, Manvi FV (2011) Development and Characterization of Solid-Lipid Microparticles of Highly Insoluble Drug Sirolimus. J Bioequiv Availab 3: 11-15.

67. Elgindy N, Elkhodairy K, Molokhia A, ElZoghby A (2011) Biopolymeric Nanoparticles for Oral Protein Delivery: Design and In Vitro Evaluation. J Nanomedic Nanotechnol 2:110.

68. Knight LC, Romano JE, Krynska B, Faro S, Mohamed FB, et al. (2010) Binding and Internalization of Iron Oxide Nanoparticles Targeted To Nuclear Oncoprotein. J Mol Biomark Diagn 1: 102.

69. Menaa B (2011) The Importance of Nanotechnology in Biomedical Sciences.J Biotechnol Biomaterial 1: 105e.

70. Amirthalingam T, Kalirajan J, Chockalingam A (2011) Use of Silica-Gold Core Shell Structured Nanoparticles for Targeted Drug Delivery System. J Nanomedic Nanotechnol 2: 119.

71. Anwunobi AP, Emeje MO (2011) Recent Application of Natural Polymers in Nanodrug Delivery. J Nanomedic Nanotechnol S4: 2.

72. Nakamura J, Nakajima N, Matsumura K, Hyon SH (2011) In Vivo Cancer Targeting of Water-Soluble Taxol by Folic Acid Immobilization. J Nanomedic Nanotechnol 2: 106

73. Nguyen KT (2011) Targeted Nanoparticles for Cancer Therapy: Promises and Challenges. J Nanomedic Nanotechnol 2: $103 \mathrm{e}$.

74. Zhao Y, Haney MJ, Mahajan V, Reiner BC, Dunaevsky A, et al. (2011) Active Targeted Macrophage-mediated Delivery of Catalase to Affected Brain Regions in Models of Parkinson's Disease. J Nanomedic Nanotechnol S4: 3.

75. Tsigelny IF, Simberg D (2011) Has the Time for In silico Design of Nanomedicines Finally Arrived? J Nanomedic Biotherapeu Discover 1: 104e.

76. Jin Y, Xin R, Tong L, Du L, Miao L (2011) Combination Anti-HIV Therapy with the Self-Assemblies of an Asymmetric Bolaamphiphilic Zidovudine/Didanosine Prodrug. Mol Pharmaceutics 8: 867-876. 